\title{
The 1997 EI Niño impact on clouds, water vapour, aerosols and reactive trace gases in the troposphere, as measured by the Global Ozone Monitoring Experiment
}

\author{
D. Loyola ${ }^{1}$, P. Valks ${ }^{1}$, T. Ruppert ${ }^{2}$, A. Richter ${ }^{3}$, T. Wagner ${ }^{4}$, W. Thomas ${ }^{5}$, R. van der $A^{6}$, and R. Meisner ${ }^{2}$ \\ ${ }^{1}$ German Aerospace Center (DLR), Rem. Sens. Technol. Inst. (IMF), Oberpfaffenhofen, 82334 Wessling, Germany \\ ${ }^{2}$ German Aerospace Center (DLR), German Rem. Sens. Data Center (DFD), Oberpfaffenhofen, 82334 Wessling, Germany \\ ${ }^{3}$ University of Bremen, P.O. Box 3304 40, 28334 Bremen, Germany \\ ${ }^{4}$ University of Heidelberg, Im Neuenheimer Feld 229, 69120 Heidelberg, Germany \\ ${ }^{5}$ Deutscher Wetterdienst (DWD), P.O. Box 1004 65, 63004 Offenbach, Germany \\ ${ }^{6}$ Royal Netherlands Meteorological Institute (KNMI), P.O.Box 201, 3730 AE De Bilt, The Netherlands
}

Received: 4 May 2005 - Revised: 23 February 2006 - Accepted: 24 February 2006 - Published: 3 March 2006

\begin{abstract}
The El Niño event of 1997/1998 caused dry conditions over the Indonesian area that were followed by large scale forest and savannah fires over Kalimantan, Sumatra, Java, and parts of Irian Jaya. Biomass burning was most intense between August and October 1997, and large amounts of ozone precursors, such as nitrogen oxides, carbon monoxide and hydrocarbons were emitted into the atmosphere. In this work, we use satellite measurements from the Global Ozone Monitoring Experiment (GOME) sensor to study the teleconnections between the El Niño event of 1997 and the Indonesian fires, clouds, water vapour, aerosols and reactive trace gases (nitrogen dioxide, formaldehyde and ozone) in the troposphere.
\end{abstract}

\section{Introduction}

The El Niño event is caused by changes of the normal pattern of the circulation over the Pacific Ocean. In normal years there is strong convection of air masses in the Western Pacific areas over Indonesia while winds move westward, which causes the balancing flow of relatively warm water at the ocean surface towards Indonesia and Australia. This leads in turn to upwelling cool water masses along the South American coast. In El Niño years we observe the reverse circulation pattern which leads to warmer water and elevated sea level along the South American continent. The increased moisture there causes frequent storms and heavy precipitation in these areas, enforced by the topographic situation. On the other hand, abnormal dry conditions occur in the Western

Correspondence to: D. Loyola

(diego.loyola@dlr.de)
Pacific area which often causes a dramatic increase of areas affected by biomass burning.

The intention of the study is to quantify the impact of El Niño events on atmospheric composition and cloud parameters. For this purpose we used backscatter radiances measured by the Global Ozone Monitoring Experiment (GOME) satellite instrument to describe the relation between the El Niño event of 1997 and changes of a number of atmospheric parameters over the Indonesian area. GOME is a nadirviewing spectrometer, launched on board the ERS-2 satellite in April 1995, which measures the Earth's radiance spectrum from UV to near-infrared wavelengths $(240-790 \mathrm{~nm})$. The typical footprint size of GOME pixels is about $320 \times 40 \mathrm{~km}^{2}$ allowing global coverage within 3 days (Burrows et al., 1999).

\section{Sea surface temperature}

Although neither a cloud parameter nor part of the atmosphere, we analysed the temporal evolution of the sea surface temperature (SST) to conclude the presence of El Niño conditions. We retrieved the sea surface temperature for October 1996 and 1997 by inverting satellite data (NOAA/AVHRR). Figure 1 shows the SST anomaly during the El Niño event of 1997/98 by comparing SST data of October 1996 and October 1997. Positive values represent a higher temperature than the zonal average; negative values show lower temperatures for that specific month. SST anomalies are computed by subtracting the monthly mean data from the climatological mean for the 1971-2000 base period. This method is appropriate to show relatively warm ocean currents induced by El Niño (lower left panel on Fig. 1) but also relatively cold areas around the Indonesian region (lower right panel on Fig. 1). 

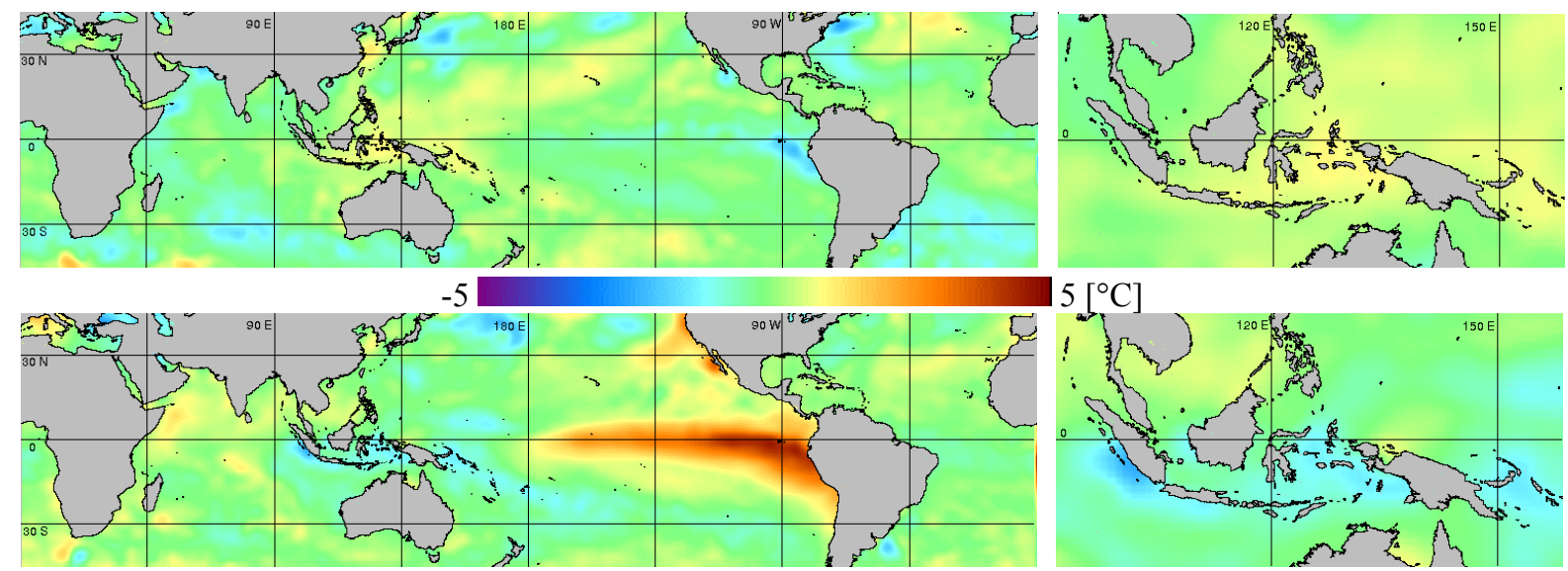

Fig. 1. SST anomaly during October 1996 (top) and October 1997 (bottom) calculated using NOAA-AVHRR data provided by NASA's JPL.

(a)

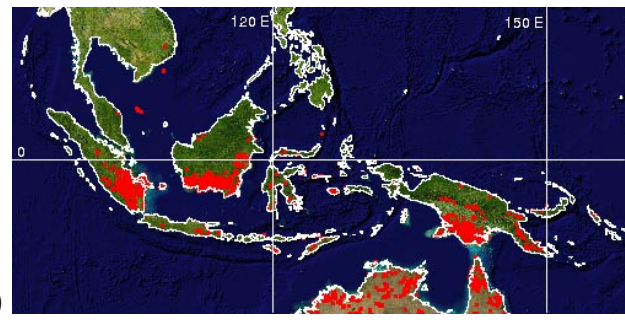

(b)

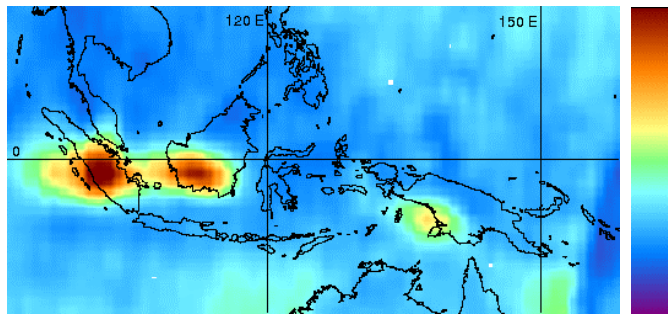

Fig. 2. (a) ATSR-2 fire count in red during October 1997 provided by ESA's world fire atlas. (b) GOME aerosol index (from -3 to 3 ) during October 1997.

\section{Fires and aerosols}

The usual rainfall surrounding Indonesia is abated during El Niño events due to changes of the atmospheric circulation. The dry conditions over the Indonesian area finally result in large scale biomass burning, especially in Kalimantan and Sumatra. Biomass burning events may be observed in a number of ways from space. Satellite sensors with high spatial resolution and a limited number of spectral channels such as the AVHRR sensor or its European counterparts (the series of ATSR instruments) can provide detailed visual information of the spatial distribution of smoke clouds and fires. Figure 2a shows the fires registered by ATSR-2 during October 1997. Highly-absorbing aerosols associated with biomass burning have been detected using the TOMS (Hsu et al., 1994) and GOME instruments (De Graaf et al., 2005). Figure $2 \mathrm{~b}$ shows the monthly averaged aerosol index over the Indonesian area as measured by GOME during October 1997.

The absorbing aerosol index is clearly higher in the Southern parts of Borneo, over Indonesia and Papua New Guinea where ATSR-2 data indicate a large number of fire spots on the ground. Fires at the Australian continent obviously produced lower aerosol masses which may be explained by the sparser vegetation that is mainly savannah.

\section{Cloud fraction, cloud-top pressure and cloud optical thickness}

Various cloud parameters can be measured with the GOME instrument. Cloud fraction is determined using broadband radiance measurements in the UV/VIS range, whilst cloudtop pressure (cloud-top height) and cloud optical thickness (cloud-top albedo) are retrieved from the spectral information in the Oxygen A-band in and around $760 \mathrm{~nm}$ (Loyola, 2004). Figure 3 illustrates the effect of the 1997-1998 El Niño on the cloud distribution over the tropics. October 1997 shows a high cloud fraction anomaly over the equatorial central Pacific area with a simultaneous decrease of the cloudtop pressure and the cloud optical thickness (Fig. 4).

Notice the low cloud fraction anomaly over large parts of the Indonesian region as a consequence of the dry conditions. The apparent cloud increase over Kalimantan and Sumatra is induced by smoke clouds (see Fig. 2b).

The cloud optical thickness anomaly indicates that the areas with an apparent cloud increase are populated with relatively thin clouds; this feature is clearly visible over Kalimantan and Sumatra (see Figs. 3 and 4). 

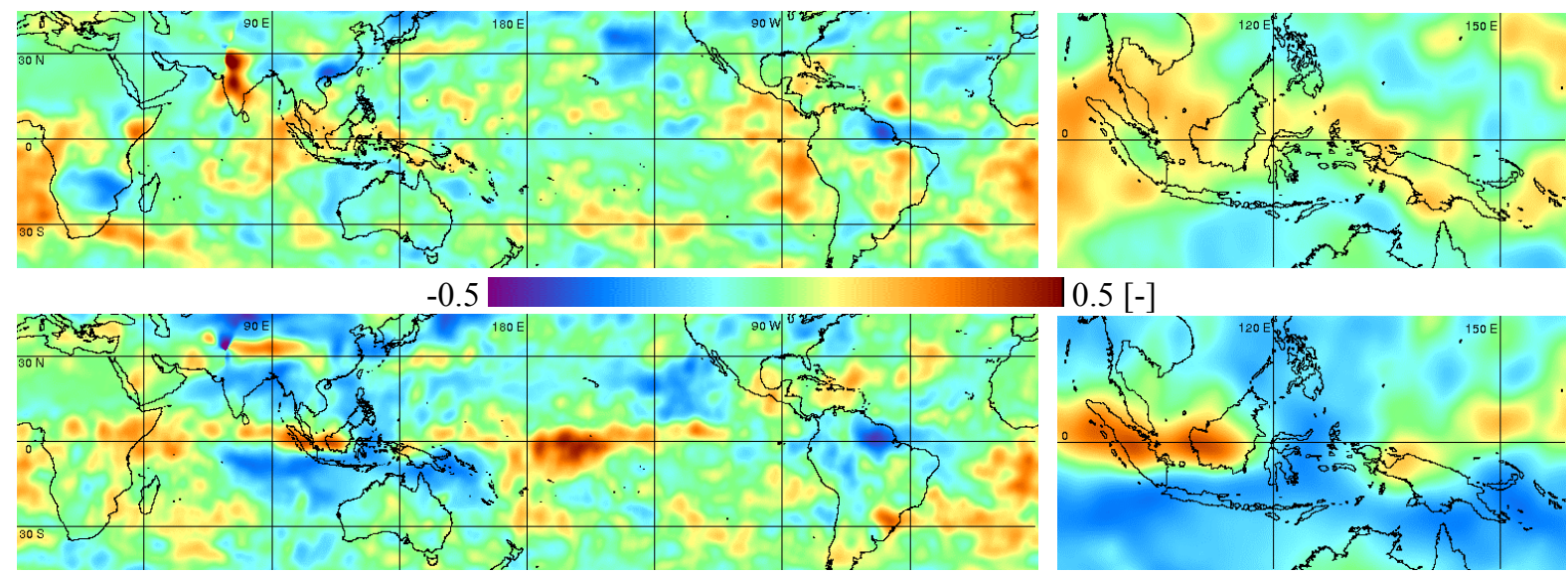

Fig. 3. Cloud fraction anomaly during October 1996 (top) and October 1997 (bottom).
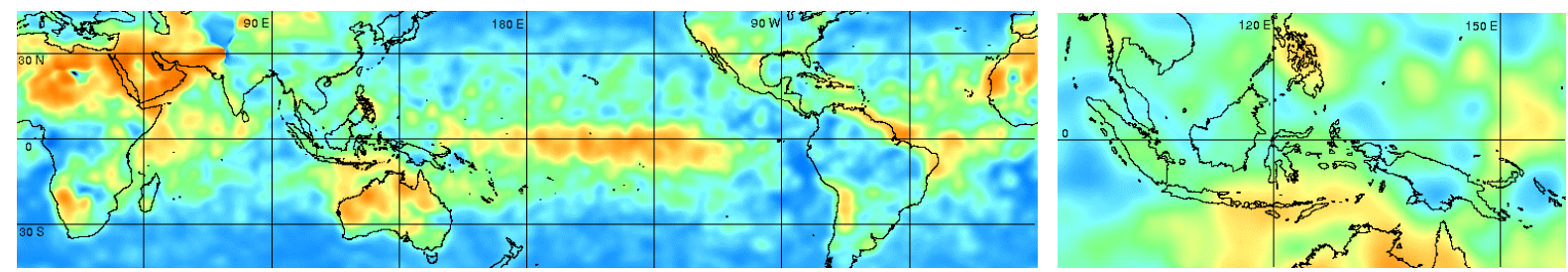

$-10$

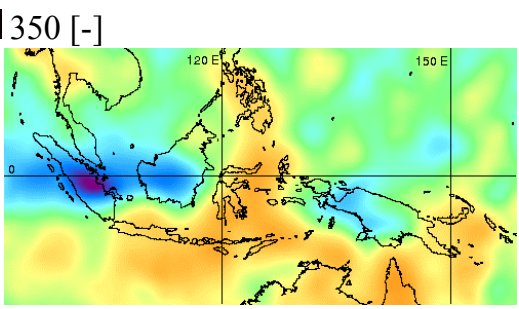

Fig. 4. Cloud optical thickness anomaly during October 1996 (top) and October 1997 (bottom).

\section{Water vapour column}

Global water vapour column distributions have been measured with the GOME instrument, using the visible wavelength region with the DOAS technique (Wagner et al., 2005). In contrast to other satellite observations of water vapour, the GOME observations are of similar sensitivity over both land and ocean.

Figure 5 illustrates the effect of the 1997/1998 El Niño on the global distribution of the water vapour abundance in the atmosphere. The relative anomalies are averaged from October 1997 to March 1998 (bottom) and for the same period of the previous year (top). Relatively small water vapour anomalies are found over the Indonesian region, indicating the dry conditions over this area. Note also the corresponding high water vapour anomaly over the equatorial Eastern Pacific during the El Niño period that clearly follows the SST anomaly in this region (Fig. 1).

As expected, there is a clear correlation between the GOME measurements of water vapour (Fig. 5) and the cloud parameters (Figs. 3 and 4).

\section{Tropospheric $\mathrm{NO}_{2}$ column}

Nitrogen dioxide $\left(\mathrm{NO}_{2}\right)$ is generated in natural (soil, lightning) and man-made (industrial production and heating, automobile combustion, biomass burning) processes. In clear air masses the bulk of $\mathrm{NO}_{2}$ is in the stratosphere while large amounts of $\mathrm{NO}_{2}$ are found in the lower troposphere, if polluted air masses over industrial regions or biomass burning areas are analyzed.

The essential step in the retrieval of the tropospheric $\mathrm{NO}_{2}$ amount from GOME measurements is the separation of stratospheric and tropospheric contributions to the signal. Measurements over a clean air area (the Pacific) are used to estimate the stratospheric $\mathrm{NO}_{2}$ column and differences between local column measurements and the clean air measurement are used to derive the tropospheric $\mathrm{NO}_{2}$ column. For the data used here, this method has been refined by using the three dimensional chemical transport model SLIMCAT to account for the longitudinal variations of stratospheric $\mathrm{NO}_{2}$ (Richter et al., 2005). Figure 6 shows GOME tropospheric $\mathrm{NO}_{2}$ anomaly during September 1996 and 1997. The large scale biomass burning over Kalimantan and Sumatra 

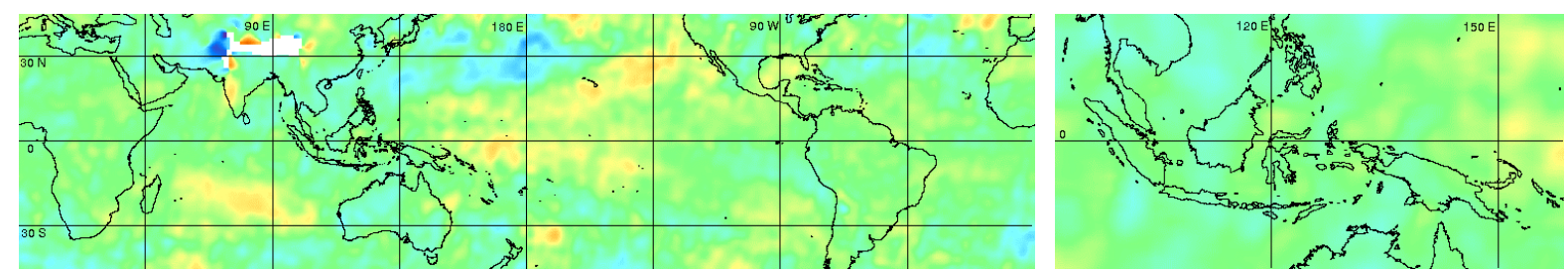

$-0.6$

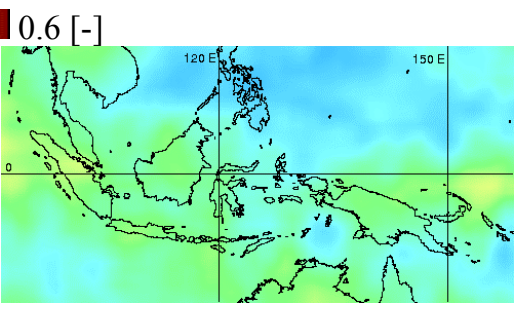

Fig. 5. Relative water vapour anomaly during 1996/1997 (top) and 1997/1998 (bottom). The anomalies are calculated with respect to the average of the non El Niño years (1996/1997, 1998/1999, 1999/2000, 2000/2001).
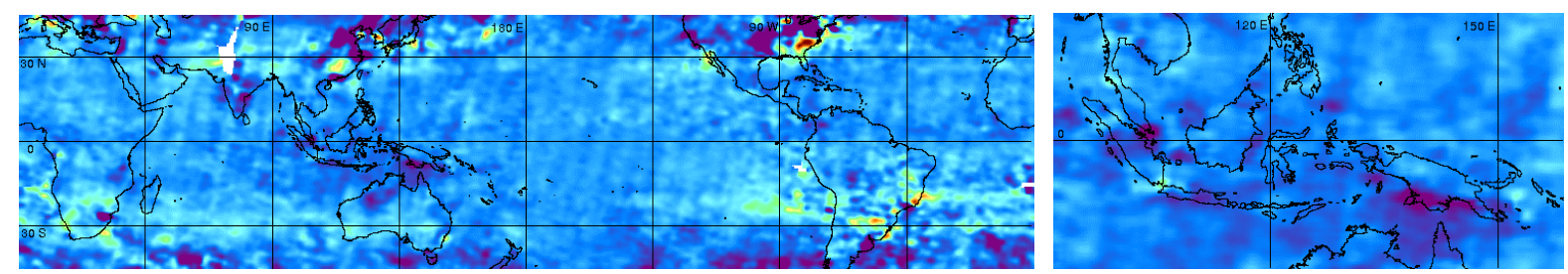

$-5 \square 15\left[10^{14} \mathrm{~mol} \mathrm{~cm}^{-2}\right]$
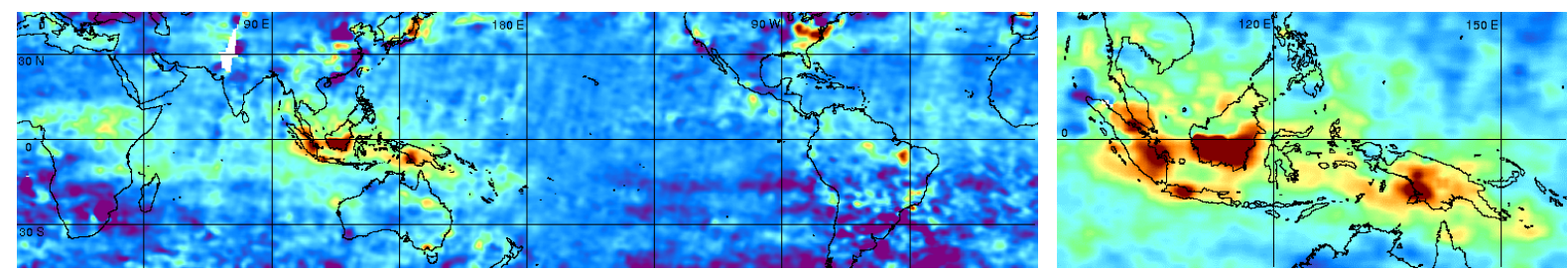

Fig. 6. Tropospheric $\mathrm{NO}_{2}$ anomaly during September 1996 (top) and September 1997 (bottom).

in September 1997 resulted in highly elevated $\mathrm{NO}_{2}$ columns over Indonesia, as can be seen in the bottom picture. Tropospheric $\mathrm{NO}_{2}$ columns of $1 \times 10^{15}-3 \times 10^{15} \mathrm{~mol} \mathrm{~cm}^{-2}$ are measured over Kalimantan in September 1997, while typical values of $2 \times 10^{14} \mathrm{~mol} \mathrm{~cm}^{-2}$ and below are found over the same area in 1996.

\section{Formaldehyde column}

Formaldehyde $\left(\mathrm{H}_{2} \mathrm{CO}\right)$ is generated directly in burning processes but also by subsequent oxidation of hydrocarbons. The building process is more effective under lower temperatures e.g., in smouldering fires. In a biomass burning scenario, formaldehyde levels are expected to be large in the troposphere, where hydrocarbon oxidation is greatly enhanced; in undisturbed atmospheres $\mathrm{H}_{2} \mathrm{CO}$ is a product of the methane cycle. Formaldehyde retrieval from GOME backscatter data in the UV wavelength region was first shown by Thomas et al. (1998).
Figure 7 shows the GOME tropospheric formaldehyde columns during October 1996 and 1997. Clearly visible are the strongly elevated formaldehyde abundance over the Indonesian region in October 1997 as a result of the large emissions of hydrocarbons during the biomass burnings.

\section{Tropospheric ozone column}

The tropospheric ozone column in the tropics has been determined from GOME ozone column and cloud measurements, using the so-called convective-cloud-differential (CCD) method (Valks et al., 2003). Figure 8 shows the tropospheric ozone column over the tropical region during October 1996 and 1997. Ozone is produced by photochemical reactions of nitrogen oxides, carbon monoxide, methane and other hydrocarbons, which are released in large amounts by tropical biomass burnings.

The elevated tropospheric ozone columns over the tropical Atlantic and Africa in October 1996 are a result of the normal 

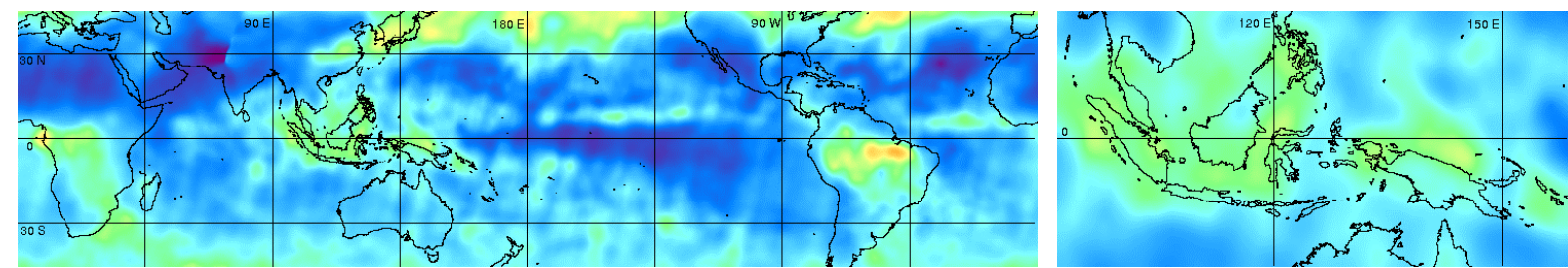

0
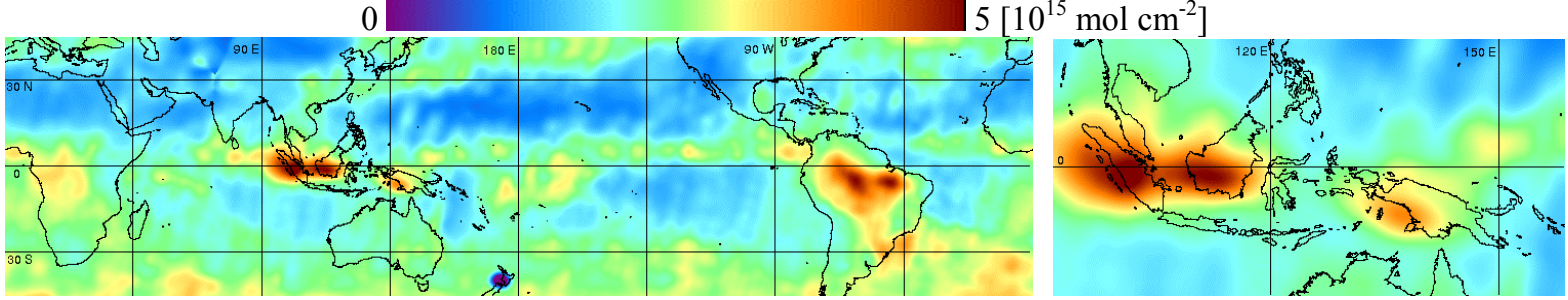

Fig. 7. Formaldehyde column during October 1996 (top) and October 1997 (bottom).
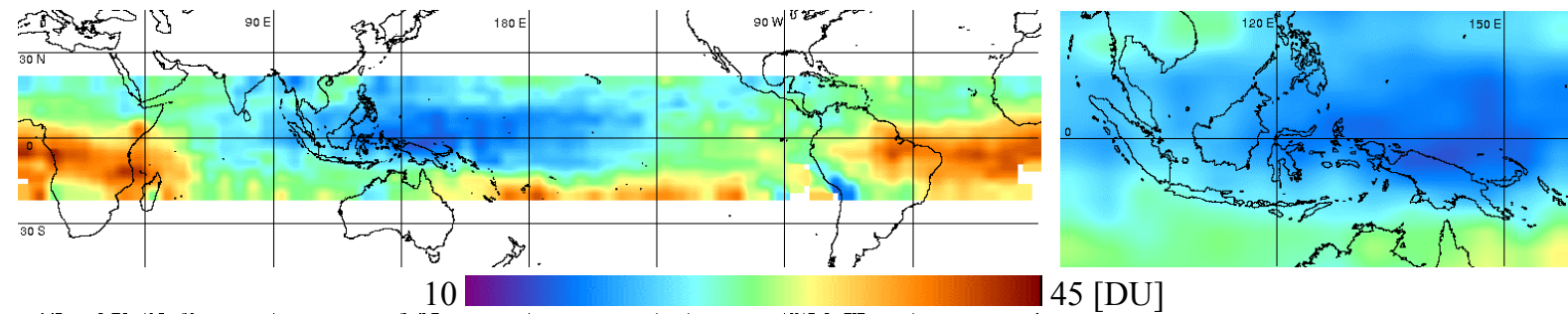

\section{5 [DU]}
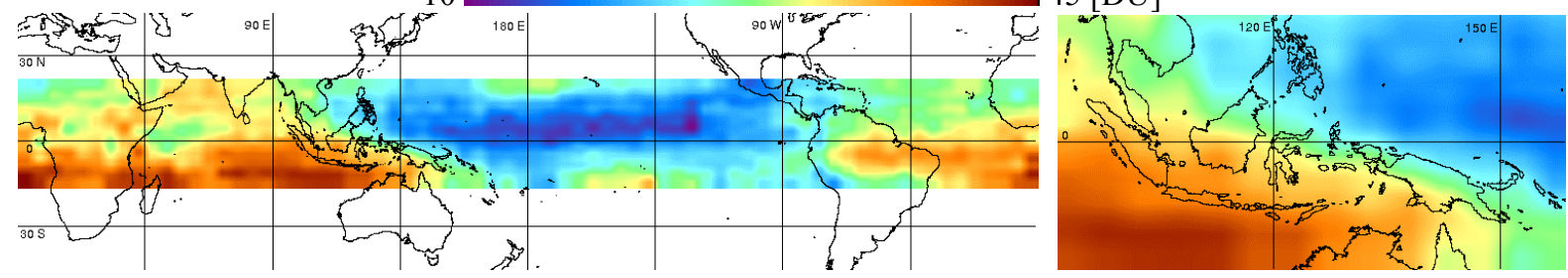

Fig. 8. Tropospheric Ozone column during October 1996 (top) and October 1997 (bottom).

burning season in southern Africa and Brazil. The effect of the forest and savannah fires over Kalimantan and Sumatra in 1997 is clearly visible in the bottom picture. In October 1997 high tropospheric ozone columns are found over the Indonesian region and a plume of elevated ozone values extends over a large region of the Indian Ocean, west of Indonesia.

During the El Niño period, ozone is concentrated in the free troposphere (mainly between 3 to $6 \mathrm{~km}$ ) above the fire areas, and transported from the source regions to the Indian Ocean with the prevailing easterlies (Thompson et al., 2001; Chandra et al., 2002).

\section{Discussion and conclusions}

We have shown the relation between the El Niño event of 1997 and the observed Indonesian fires, changes in cloud parameters, and the atmospheric composition in the troposphere (water vapour, aerosols and reactive trace gases such as nitrogen dioxide, formaldehyde and ozone) using GOME satellite measurements.
Changes of the sea surface temperature, cloudiness and water vapour, the latter two quantities derived from GOME data, clearly indicated the presence of an El Niño event in autumn 1997. Sea surface temperature increased along the South American coastline in equatorial regions while the cloudiness was low over South East Asia and cloud-top pressure increased. Abnormally dry conditions over South-East Asia were clearly visible in the decreased atmospheric water vapour content as retrieved from GOME data. This caused finally heavy biomass burning in large regions of Indonesia, Kalimantan and Java, partly because the traditional slashand-burn farming method went out of control. The fires are responsible for a strong increase of soot and dust-like aerosols with high absorption capabilities. A second effect of the fires is the enhancement of chemically active species in the troposphere, which originate either directly from burning processes (nitrogen dioxide, formaldehyde, carbon monoxide) or stem from photochemical reactions (ozone).

We could show that especially tropospheric nitrogen dioxide and formaldehyde levels largely increased by a factor of 10 over the areas where fires were located. Similarly the 
tropospheric ozone content increased by a factor of 3 . As result of the large emissions combined with rapid transport, even the short lived species $\left(\mathrm{NO}_{2}, \mathrm{H}_{2} \mathrm{CO}\right)$ affected a large area and ozone was enhanced all the way to Africa.

The anomalies presented are a good example for dramatic changes of the environment that are initially caused by a change of the atmospheric circulation pattern and its subsequent impact on the ocean state.

Acknowledgements. The authors gratefully thank the reviewers for detailed comments; the paper has benefited significantly as a result. ESA is acknowledged for facilitating the access to ATSR-2 and GOME data, as well as NASA for the SST data. Part or this work was supported by the European Union through the ACCENT project.

Edited by: P. Fabian and J. L. Santos

Reviewed by: H. Dijkstra and another anonymous referee

\section{References}

Burrows, J. P., Weber, M., Buchwitz, M., Rozanov, V., LadstaetterWeissenmayer, A., Richter, A., de Beek, R., Hoogen, R., Bramstedt, K., Eichmann, K.-U., Eisinger, M., and Perner, D.: The Global Ozone Monitoring Experiment (GOME): Mission concept and first scientific results, J. Atm. Sci., 56, 151-175, 1999.

Chandra, S., Ziemke, J. R., Bhartia, P. K., and Martin, R. V.: Tropical tropospheric ozone: Implications for dynamics and biomass burning, J. Geophys. Res., 107, 4188, doi:10.1029 /2001JD000447, 2002.
De Graaf, M., Stammes, P., Torres, O., and Koelemeijer, R. B. A.: Absorbing Aerosol Index: Sensitivity analysis, application to GOME and comparison with TOMS, J. Geophys. Res., 110, D01201, doi:10.1029/2004JD005178, 2004.

Hsu, N. C., Herman, J. R., Bhartia, P. K., Seftor, C. J., Torres, O., Thompson, A. M., Gleason, J. F., Eck, T. F., and Holben, B. N.: Detection of Biomass Burning Smoke from TOMS measurements, Geophys. Res. Lett., 23, 745-748, 1994.

Loyola, D.: Automatic Cloud Analysis from Polar-Orbiting Satellites using Neural Network and Data Fusion Techniques, IEEE International Geoscience and Remote Sensing Symposium, 4, 2530-2534, 2004.

Richter, A., Burrows, J. P., Nüß, H., Granier, C., and Niemeier, U.: Increase in tropospheric nitrogen dioxide over China observed from space, Nature, 437, 129-132, doi:10.1038/nature04092, 2005.

Thomas, W., Hegels, E., Slijkhuis, S., Spurr, R., and Chance, K.: Detection of biomass burning combustion products in Southeast Asia from backscatter data taken by the GOME spectrometer, Geophys. Res. Lett., 25, 1317-1320, 1998.

Thompson, A. M., Witte, J. C., Hudson, R. D., Guo, H., Herman, J. R., and Fujiwara, M.: Tropical tropospheric ozone and biomass burning, Science, 291, 2128-2132, 2001.

Valks, P. J. M., Koelemeijer, R. B. A., van Weele, M., van Velthoven, P., Fortuin, J. P. F., and Kelder, H.: Variability in tropical tropospheric ozone: Analysis with Global Ozone Monitoring Experiment observations and a global model, J. Geophys. Res., 108, 4328, doi:10.1029 /2002JD002894, 2003.

Wagner, T., Beirle, S., Grzegorski, M., Sanghavi, S., and Platt, U.: El-Niño induced anomalies in global data sets of total column precipitable water and cloud cover derived from GOME on ERS2, J. Geophys. Res., 110, D15104, doi:10.1029/2005JD005972, 2005. 